\title{
Road mitigation using tunnels and fences promotes site connectivity and population expansion for a protected amphibian
}

\author{
Laurence E Jarvis $^{1} \cdot$ Michael Hartup $^{1} \cdot$ Silviu O Petrovan ${ }^{1,2}$ (1) \\ Received: 31 August 2018 / Revised: 28 January 2019 / Accepted: 11 February 2019 / Published online: 26 February 2019 \\ (C) The Author(s) 2019
}

\begin{abstract}
Habitat loss and fragmentation due to urbanisation and road developments have substantial impacts on amphibian populations and road mitigation measures are increasingly used in order to reduce such risks. However, numerous important questions remain unanswered on the actual effectiveness of such ecological road mitigation projects. We used specially adapted time-lapse recording cameras and a custom image analysis script to monitor the amphibian usage and effectiveness of a multi-tunnel mitigation site in northern England over 4 years and used before-and-after pond survey data to evaluate the mitigation results from a population trend perspective. We monitored four amphibian species, including the European protected great crested newt (Triturus cristatus), the main target of amphibian road mitigation in the UK. Despite substantial evidence of mitigation rejection and U-turn movements inside the tunnels, overall, most amphibians entering tunnels successfully used them to move between the different parts of the site separated by the road. Road fences appeared effective for preventing amphibian road mortality and site connectivity was re-established via the wildlife passage system, with multiple new ponds across the road colonised by amphibians. Unlike frogs and toads, tunnel usage by newts was strongly autumn based, indicating that such systems are mainly suitable for supporting newt dispersal movements between breeding areas. The great crested newt population increased rapidly over the course of the monitoring period, suggesting that, together with habitat replacements and improvements, the road mitigation measures were effective at maintaining site connectivity and as a population conservation measure.
\end{abstract}

Keywords Road ecology · Amphibian connectivity $\cdot$ Road tunnels $\cdot$ Great crested newt $\cdot$ Triturus cristatus

\section{Introduction}

The unprecedented expansion of transport infrastructure over the past decades has had major impacts on amphibian populations worldwide (Fahrig et al. 1995; Glista et al. 2008; Beebee 2013), causing habitat loss, pollution and fragmentation as well as substantial rates of road traffic mortality (Hels and Buchwald 2001; Mazerolle 2004; Petrovan and Schmidt 2016). In response to the growing concerns for species conservation and public pressure, ecological mitigation measures have been increasingly implemented since the 1980s,

This article is part of the Topical Collection on Road Ecology Guest Editor: Marcello D'Amico

Silviu O Petrovan

sop21@cam.ac.uk

Froglife, 1 Loxley, Peterborough PE4 5BW, UK

2 Conservation Science Group, Department of Zoology, University of Cambridge, David Attenborough Building, Cambridge CB23CZ, UK especially in Europe and North America, in an effort to prevent road mortality and re-establish habitat connectivity. Fence and tunnel systems (also called eco-passages, road underpasses or wildlife culverts) are currently considered the most promising solution for amphibians (Schmidt and Zumbach 2008; Lesbarreres and Fahrig 2012; Beebee 2013) and are now regularly implemented across the globe for new infrastructure projects. Numerous studies have attempted to monitor the success of such tunnels, usually using drift fences and pitfall traps at the entrances to tunnels (e.g. Jolivet et al. 2008; Pagnucco et al. 2012; Matos et al. 2017). However, tunnel usage by amphibians appears highly variable both within and between species and pitfall trapping can introduce bias in the data by restricting animal movement. Additionally, it typically requires licenced personnel and is inherently expensive given that traps need to be checked at least twice daily. Pagnucco et al. (2012) found that the crossing success rate in the long-toed salamander (Ambystoma macrodactylum) in North America was 23\% in immigrating individuals but only $1 \%$ in emigrating individuals, highlighting large seasonal differences within the same population. 
Smith et al. (2010) using remotely triggered cameras in under road tunnels concluded that installation of road tunnels provides an effective and safe route of travel for a diversity of animals including long-toed salamanders (A. macrodactylum), especially if drift fences are in place to direct amphibians towards tunnels. However, other studies from North America suggest that road culverts do not always benefit amphibians. In New York State, spotted salamanders (A. maculatum) and American toads (Anaxyrus americanus) individuals did not use road culverts, potentially due to local conditions such as snowmelt in the culverts and ineffective drift fence system (Patrick et al. 2010). Similarly, Allaback and Laabs (2003) found that only $9 \%$ of the 44 long-toed salamanders (A. macrodactylum) that encountered the drift fence passed through the two tunnels situated closest to the breeding pond, with many individuals appearing disoriented when they first encountered the tunnel entrances. In Europe, using fluorescent powder and pattern recognition to monitor movements and behaviour, Matos et al. (2018) showed that most great crested newts (Triturus cristatus) did not follow road mitigation drift fences and only $3 \%$ of all individuals encountered along the fences reached the tunnels entrances, thus suggesting that fences can act as barriers to movement. However, adequate and uninterrupted fences are required for preventing amphibian road mortality, even in the presence of mitigation tunnels (Hill et al. 2018).

Whilst many studies have described mitigation usage, few studies have examined the actual effectiveness of road tunnels for amphibian species (Smith et al. 2018). Jolivet et al. (2008) in a study of common toad (Bufo bufo) and common frog (Rana temporaria) populations in Switzerland found marked differences in the use of tunnels by adults and juveniles as well as between the two species, with frogs proportionately using tunnels more frequently compared to toads. This resulted in little or no population increase for several years post-tunnel construction. However, they confirmed juvenile build-up in the population over time which resulted in overall population increases after several years (Jolivet et al. 2008).

Whilst the effectiveness of tunnel and fence systems in improving the population conservation status for different species remains insufficiently understood, overall, this is particularly the case for European newt species, where almost no information is available (Schmidt and Zumbach 2008; Matos et al. 2017). This includes the great crested newt, a European protected species which has undergone substantial declines in the UK (Langton et al. 2001) but remains relatively widespread and locally abundant and is a main target of road mitigation schemes (Matos et al. 2017). Whilst newts generally appear to be far less frequently encountered on roads or killed by car traffic compared to most other amphibian species (Petrovan and Schmidt 2016; Kyek et al. 2017), road networks can severely disrupt dispersal movements, which are essential for maintaining metapopulation dynamic and viability (Halley et al. 1996; Griffiths et al. 2010). Understanding how specific road mitigation schemes affect population status over several years could fundamentally improve our understanding of the viability and cost-effectiveness of such schemes for informed large-scale implementations. This however requires a more indepth assessment and monitoring, as mitigation usage on its own is insufficient to describe the overall effectiveness in a population context (Van der Grift et al. 2013; Van der Ree et al. 2015). Equally, mitigation schemes focused in particular on one species should ideally benefit, or at least not have negative consequences, for other locally present species and wider area biodiversity. We monitored a road mitigation scheme in spring and autumn for 4 years and used novel automated technology and analysis to understand the movement patterns of four amphibian species inside the mitigation scheme. Finally, we related the results with population assessments derived from standardised, multi-method and repeated annual surveys.

\section{Materials and methods}

\section{Study area}

The study area was located in Yorkshire, UK (exact location anonymised as the project is ongoing and the site is privately owned and not opened to the public). Prior to 2012, the main site consisted of three main ponds and several seasonally wet ditches, situated in farmland pasture at the edge of a large urban site. As part of ecological surveys, two of the ponds were found to support breeding populations of amphibians, including great crested newts, which are protected by law and thus require licenced mitigation (English Nature 2001). In 2013, the main part of the site was used for commercial buildings, access roads and car park. As a water management and ecological mitigation measure, a series of new ponds were created in the immediate area, with eight other water management ponds further away. This included five 8-12-m-diameter amphibian receptor ponds (which split into six ponds when water levels were low), where the newts and other amphibians captured on site were translocated (Fig. 1). In total, 225 great crested newts, adults and young juveniles, were captured and translocated as well as over 450 mostly larval stage juvenile smooth newts (Lissotriton vulgaris), 76 common toads, mostly terrestrial stage juveniles, and 16 common frogs, mostly adults. Between the receptor ponds and the original capture ponds and locations, a new access road was built, provisioned with cycle tracks and pedestrian areas. During road construction, four amphibian tunnels - polymer concrete tunnels with open slots at the top (KT 500 climate tunnel with climate slots; KST 700 stilt tunnel sections and KP 1000 entrances, produced by ACO Germany)-were installed in pairs, $12 \mathrm{~m}$ apart between the two pairs. Each tunnel was $0.5 \mathrm{~m}$ diameter and $24 \mathrm{~m}$ long with the open top vents only in the road section (11 m wide) 
Fig. 1 Map of the study area showing the amphibian mitigation zone, where amphibians were initially translocated to, the roads and the mitigation system as well as the water management ponds. Buildings and car parks occupy most of the area north of the mitigation scheme

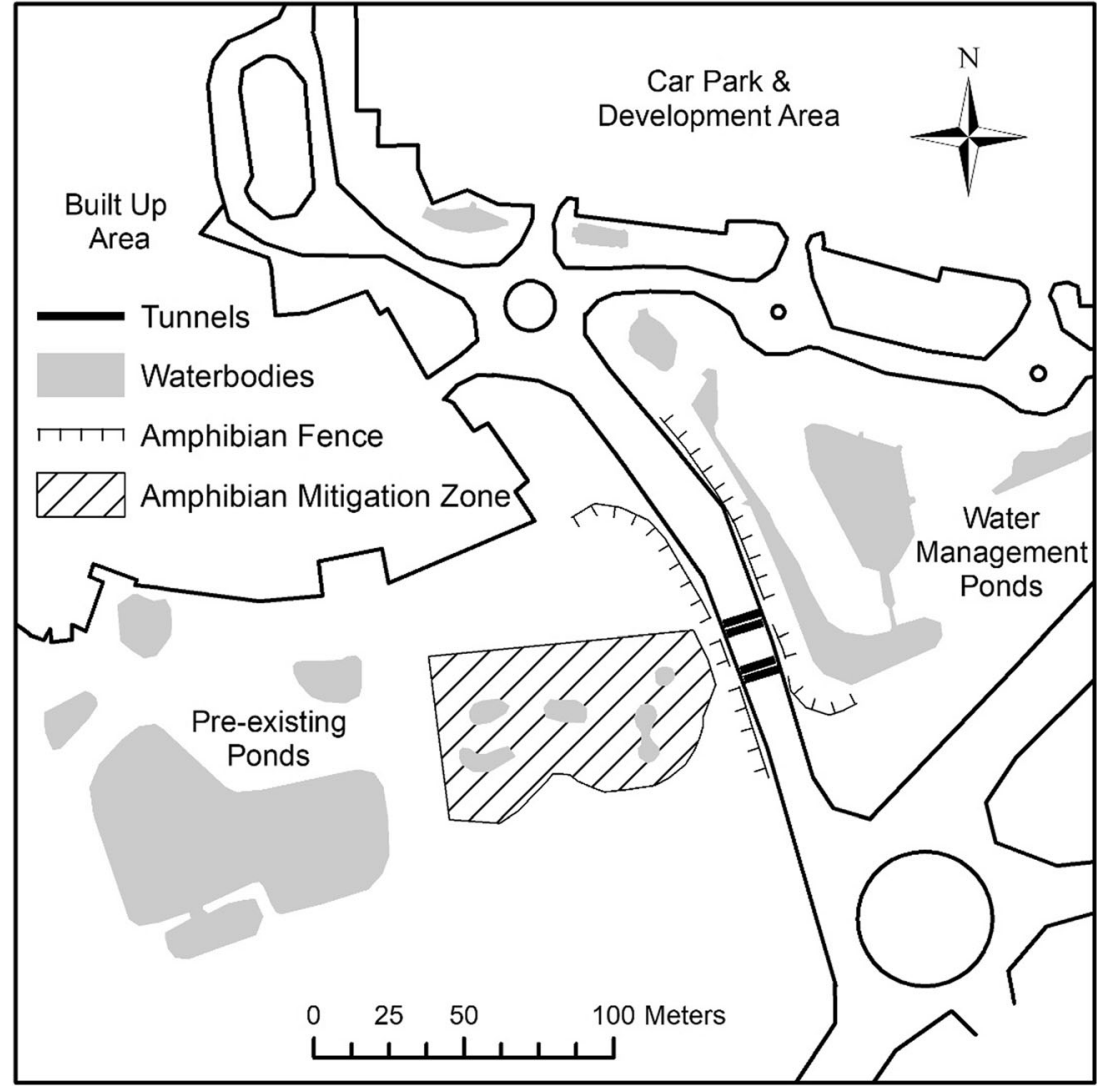

and not on the green verges, cycle track, and pedestrian areas. Both sides of the road in the tunnel section were provisioned with heavy-duty, one way ACO black plastic fencing $(0.4 \mathrm{~m}$ above ground, 120-135 $\mathrm{m}$ long on each side) aiming to prevent amphibian movements onto the road. The tunnels lie within 20-30 m of the receptor ponds on one side of the road and within 10-20 m of newly created water management ponds on the other side of the road (Fig. 1). The furthest attenuation pond is approximately $200 \mathrm{~m}$ from the tunnels. Suitable terrestrial habitat lies adjacent to the tunnel entrances on both sides of the road, linking to the nearest ponds.

\section{Tunnel monitoring}

As tunnels in each pair were immediately adjacent to each other and thus unlikely to have different encounter rates by amphibians, only one tunnel from each pair was monitored, with 41 to 62 annual monitoring days over spring and autumn during 4 years, from September 2014 to November 2017. The two tunnels which were not monitored were partly blocked to prevent amphibians and other small vertebrates from entering them. On the side of the road next to the amphibian mitigation zone, we installed two specially adapted time-lapse infrared cameras (Brinno TLC200 Pro) in weatherproof casing, with externally mounted infrared $960 \mathrm{~nm}$ LED and wide angle $170^{\circ}$ lenses in each of the two monitoring tunnels. Custom- made sliding aluminium frames fixed the cameras approximately $1.5 \mathrm{~m}$ inside the entrance to each tunnel on the roof, with cameras facing the tunnel floor. The cameras were only accessible using an extendable pole. The cameras recorded an image every $15 \mathrm{~s}$ over every 24 -h period in the autumn (September to November) and spring (March to May). This equates to approximately 5700 images every day from each camera and each image was timestamped and received an automated identification code. The cameras were able to record movement of all amphibian species moving into and out of the tunnels. The high-quality images and infrared lighting allowed us to identify species, sex (where possible given the dorsal view only) and age class of individuals using the tunnels (adult or juvenile) (Fig. 2). Every 5 days, the cameras were serviced by changing re-chargeable batteries for cameras and infrared lights, data download onto a secure external hard drive and spot-checking the recorded images to ensure unobstructed view in the tunnels.

\section{Population surveys}

In the period April to June, from 2014 to 2017, six standard torch light and four bottle trapping pond surveys were carried out annually by licenced consultants in the five receptor ponds. In addition, four torch surveys were conducted annually on the newly created water management ponds. All surveys followed 


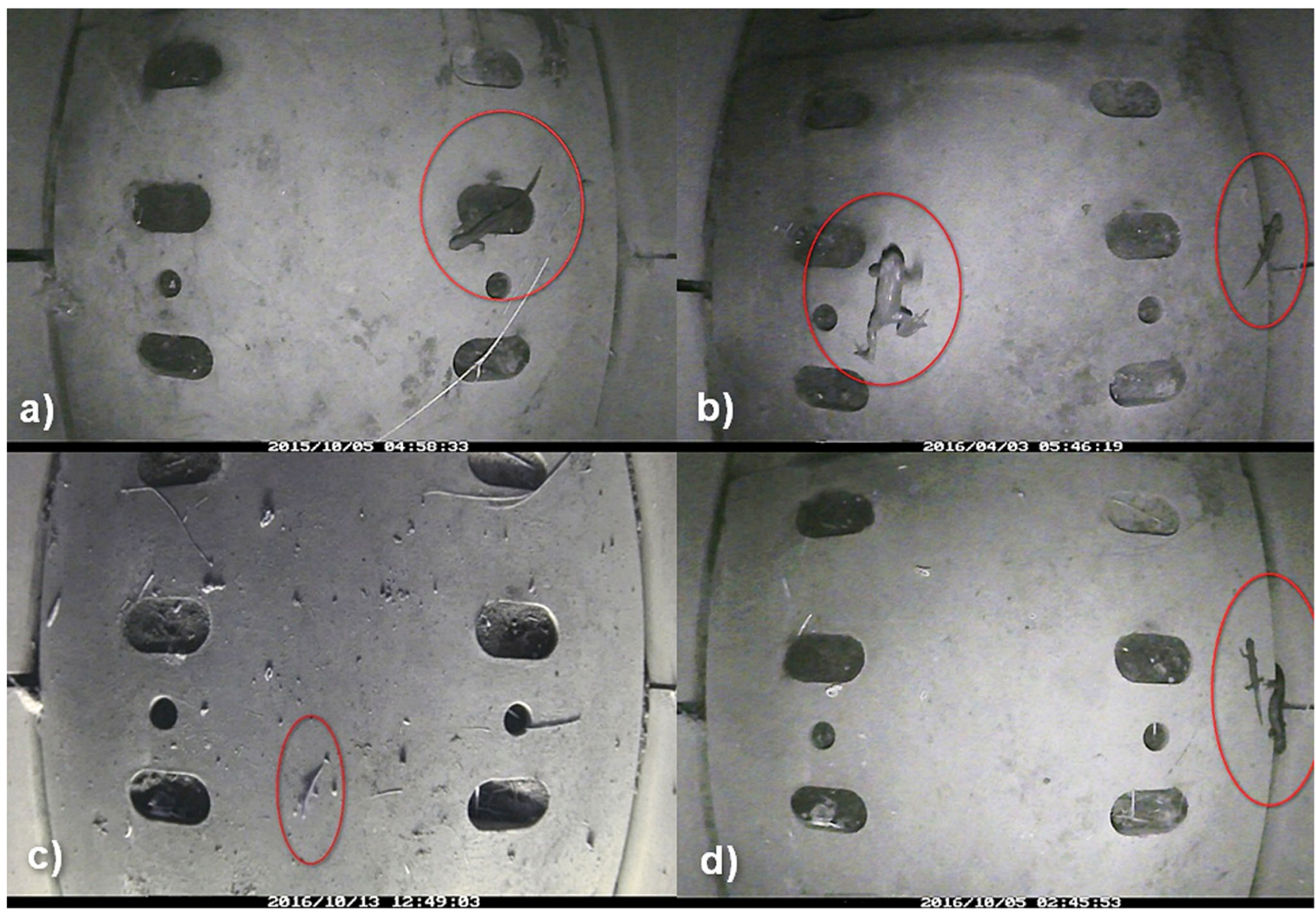

Fig. 2 Timestamped images of amphibian observations in the two monitored tunnels using customised time-lapse cameras. a Adult male great crested newt (Triturus cristatus). b Male common toad (Bufo

standard UK guidelines for professional ecological consultants (English Nature 2001). During night torch surveys, ecologists walked the perimeter of each pond using 1 million $\mathrm{CP}$ Clulite ${ }^{\circledR}$ lithium-ion power torches scanning the perimeter shoreline. The total number of amphibian species was recorded along with sex (where possible) and age class (adult/sub-adult/juvenile). During bottle trapping, modified 2-1 plastic bottles were partially submerged and anchored at dusk into the perimeter of each pond, at approximately 2-m intervals. Traps were collected the following morning before 9:00 am and the total number of each amphibian species captured was recorded along with sex (where possible) and age class (adult/sub-adult/juvenile). During the entire period of amphibian surveys, as well as during the full duration of the camera monitoring and servicing, the road surface where the amphibian fences were installed was observed from the side of the road and crossed multiple times during both daytime and nighttime.

\section{Data analysis}

We used a specially developed motion detection script based on frame difference using Python and Open CV to perform an bufo) and juvenile great crested newt. c Young juvenile smooth newt (Lissotriton vulgaris) during the daytime. d Juvenile and adult male great crested newt

initial automated analysis of the image data. This removed between 70 and $95 \%$ of the images where no movement occurred and was calibrated specifically to the site. The method was independently tested by different researchers analysing unknowingly the same large dataset in a different project and was found to be extremely robust, with less than $0.5 \%$ differences in the total number of observations (over 650 amphibian observations) for complete manual image analysis compared to the automated script (Helldin et al. 2015). Following automated analysis, an experienced researcher manually checked all "positive" motion detection selected images to identify for each observation the amphibian species, sex (where possible), age class and directionality through the tunnels.

The number of individuals of each species and age class (where possible) making complete and incomplete crossings was recorded. A complete crossing was calculated by subtracting the total number of inward and the total number of outward movements observed for a given species and age class in a 24-h period, starting at mid-day. This is because peak amphibian movement occurs at night. For example, if four inward and three outward movements were observed for adult great crested newts in a $24-\mathrm{h}$ period, this would equal 
one complete crossing since one individual did not return back through the tunnel. This calculation gives the minimum number of possible complete crossings since the movement of individuals was bidirectional and ensures no false complete crossings were recorded. The tunnel success rate is defined as the proportion of individuals within each species (and age class where applicable) making complete crossings out of the total number of observations. Proportion data for success rate were arcsine transformed and a 2-way analysis of variance applied to determine whether there was a difference between the success rate between species (adults only when no juveniles were observed) and tunnels.

Multiple analysis of variance (MANOVA) was applied using the statistical software Minitab to determine whether there was a significant difference in the numbers of each species observed between seasons, years, age class or tunnel for each species. The direction of travel for each species was calculated by counting the number of inward and outward movements made for all complete crossings. Chi-square analysis was performed to determine whether there was a significant association between inward and outward movement for each species. Total daily rainfall and minimum daily temperature records were obtained from a local weather station, located approximately $5 \mathrm{~km}$ to the south of the study area. Linear regression analysis was performed to determine whether there was a correlation between the minimum daily temperature and total daily rainfall and the number of captures of individuals from each species. Peak movement times were calculated by summing all observations for each species in each hour within a 24-h period across spring and autumn monitoring periods.

Patch occupancy modelling (Mackenzie et al. 2006) was used to estimate population size in each pond based on count data from within-year repeat pond surveys from 2014 to 2017. As the numbers of ponds were too small to allow sufficient replication for a robust stand-alone model, we used a recently developed model from a sample of 65 ponds occupied by great crested newts in England (Furnborough 2016). In the original model development, several covariates were initially considered including fish presence, water turbidity, aquatic vegetation, temperature, date and pond size and used a standard nighttime newt survey technique with three to five repeated torch surveys in a single season (Furnborough 2016). The original models included observations of a total of 2337 adult great crested newts in 2013 and 2749 in 2014 in 65 ponds, with top selected models indicating newt abundance to be influenced by fish presence and pond size (Furnborough 2016).

\section{Results}

In total, 243 adult great crested newts, 322 juvenile great crested newts, 67 adult smooth newts, 161 juvenile smooth newts, 69 adult common frogs and 189 common toads were observed in the tunnels (Table 1) (Fig. 2). No juvenile common frogs or common toads were recorded in the tunnels. During the entire monitoring period of the tunnels and ponds in 2014-2017, no amphibians were observed killed or alive on the road surface in the fenced section near the ponds and tunnels. In addition to amphibians, numerous other species were recorded using the tunnels, including invertebrates and small mammals such as brown rats (Rattus norvegicus), field voles (Microtus agrestis), wood mice (Apodemus sylvaticus), common shrew (Sorex araneus), West European hedgehog (Erinaceus europaeus) and most surprisingly, several observations of European otters (Lutra lutra), previously unknown to be present at the site. We found no evidence of amphibian predation inside the tunnels or near the tunnel entrances.

\section{Tunnel crossing success rate}

There was no significant difference in the success rate between species $\left(F_{3,55}=0.78, p=0.52\right)$ and between tunnels $\left(F_{1,55}=1.84, p=0.18\right)$. The tunnel crossing success rate of adult great crested newts ranged between 57.1 and $82.6 \%$ (mean $74.5 \%$ ) (Table 1). This is in comparison to a success rate of between 0 and $81.8 \%$ (mean $70.2 \%$ ) for juvenile great crested newts. There was no significant difference in the success rate between adult and juvenile great crested newts $\left(F_{1,27}=0.49, p=0.49\right)$. The success rate for adult smooth newts was more variable, varying between 0 and $100 \%$ (mean $80.6 \%$ ). Juvenile smooth newts had success rates of between 27.3 and $100 \%$ (mean $66.5 \%$ ). There was no significant difference in the success rate between adult and juvenile smooth newts $\left(F_{1,27}=0.30, p=0.59\right)$. Common frogs had tunnel success rates varying between 50.0 and $100 \%$ (mean $78.3 \%$ ) whilst the success rates of common toads ranged between 55.6 and $100 \%$ (mean $69.3 \%$ ).

\section{Tunnel usage}

The numbers of great crested newts observed using the tunnels each season ranged between 7 and 105 (mean 35) for adults and between zero and 164 (mean 46) for juveniles (Table 1). A significantly higher number of great crested newts were recorded inside the tunnels in autumn compared to spring $\left(F_{1,27}=16.00, p=0.001\right)$. There was no significant difference between year, age class or tunnel. The number of smooth newts per season ranged between zero and 18 (mean 10) for adults and between 3 and 58 (mean 23) for juveniles. As with great crested newts, a significantly higher number of smooth newts used the tunnels in autumn than in spring but there was no significant difference in the numbers observed between years, age or tunnel.

There was no significant difference in the numbers of common frogs observed between seasons, years or tunnels. However, more common toads used the tunnels in the spring 
Table 1 Total and mean number of individuals of each species and age class observed in tunnels in 2014-2017. $N$, number of individuals; $F$, number of full crossings; $S$, crossing success rate. Total values given for $N$ and $F$; mean values given for $S$

\begin{tabular}{|c|c|c|c|c|c|c|c|c|c|c|}
\hline \multirow[t]{2}{*}{ Time period } & \multirow[t]{2}{*}{ Number nights surveyed } & \multicolumn{3}{|c|}{ Adult great crested newt } & \multicolumn{3}{|c|}{ Juvenile great crested newt } & \multicolumn{3}{|c|}{ Adult smooth newt } \\
\hline & & $N$ & $F$ & $S$ & $N$ & $F$ & $S$ & $N$ & $F$ & $S$ \\
\hline Autumn 2014 & 41 & 14 & 9 & $64.3 \%$ & 49 & 32 & $65.3 \%$ & 0 & 0 & $0.0 \%$ \\
\hline Spring 2015 & 42 & 7 & 4 & $57.1 \%$ & 0 & 0 & $0.0 \%$ & 5 & 4 & $80.0 \%$ \\
\hline Autumn 2015 & 51 & 41 & 30 & $73.2 \%$ & 31 & 22 & $71.0 \%$ & 18 & 15 & $83.3 \%$ \\
\hline Spring 2016 & 53 & 18 & 11 & $61.1 \%$ & 11 & 9 & $81.8 \%$ & 16 & 9 & $56.3 \%$ \\
\hline Autumn 2016 & 49 & 46 & 38 & $82.6 \%$ & 164 & 115 & $70.1 \%$ & 2 & 2 & $100.0 \%$ \\
\hline Spring 2017 & 62 & 12 & 8 & $66.7 \%$ & 21 & 17 & $81.0 \%$ & 8 & 8 & $100.0 \%$ \\
\hline Autumn 2017 & 62 & 105 & 81 & $77.1 \%$ & 46 & 31 & $67.4 \%$ & 18 & 16 & $88.9 \%$ \\
\hline Total/mean & 360 & 243 & 181 & $74.5 \%$ & 322 & 226 & $70.2 \%$ & 67 & 54 & $80.6 \%$ \\
\hline \multirow[t]{2}{*}{ Time period } & \multirow[t]{2}{*}{ Number nights surveyed } & \multicolumn{3}{|c|}{ Juvenile smooth newt } & \multicolumn{3}{|c|}{ Adult common frog } & \multicolumn{3}{|c|}{ Adult common toad } \\
\hline & & $N$ & $F$ & $S$ & $N$ & $F$ & $S$ & $N$ & $F$ & $S$ \\
\hline Autumn 2014 & 41 & 11 & 3 & $27.3 \%$ & 15 & 11 & $73.3 \%$ & 18 & 10 & $55.6 \%$ \\
\hline Spring 2015 & 42 & 6 & 4 & $66.7 \%$ & 5 & 5 & $100.0 \%$ & 21 & 13 & $61.9 \%$ \\
\hline Autumn 2015 & 51 & 41 & 27 & $65.9 \%$ & 31 & 24 & $77.4 \%$ & 17 & 16 & $94.1 \%$ \\
\hline Spring 2016 & 53 & 7 & 4 & $57.1 \%$ & 8 & 7 & $87.5 \%$ & 95 & 67 & $70.5 \%$ \\
\hline Autumn 2016 & 49 & 58 & 41 & $70.7 \%$ & 5 & 3 & $60.0 \%$ & 3 & 3 & $100.0 \%$ \\
\hline Spring 2017 & 62 & 3 & 3 & $100.0 \%$ & 3 & 3 & $100.0 \%$ & 33 & 20 & $60.6 \%$ \\
\hline Autumn 2017 & 62 & 35 & 25 & $71.4 \%$ & 2 & 1 & $50.0 \%$ & 2 & 2 & $10.0 \%$ \\
\hline Total/mean & 51 & 161 & 107 & $66.5 \%$ & 69 & 54 & $78.3 \%$ & 189 & 131 & $69.3 \%$ \\
\hline
\end{tabular}

compared to autumn $\left(F_{1,13}=7.59, p=0.025\right)$, corresponding to peak movements of adults occurring around the breeding period. There was no significant difference in the numbers of toads observed between years or tunnels.

\section{Sex ratio}

The sex of great crested and smooth newts was often impossible to determine (males were only clearly recognisable when the dorsal crest could be observed but the crest is greatly reduced during the terrestrial life stage) and therefore analysis was not possible. When sex was identified, a greater number of females appeared to make tunnel crossings, especially in autumn 2015 where 24 females were observed compared to 7 males. The same pattern was observed in smooth newts with 22 female and 7 male observations across the 2014-2017 monitoring period (Table 2). However, caution should be taken when interpreting these results since the sex remained undetermined in $42 \%$ of great crested newts and $57 \%$ of smooth newts.

\section{Influence of weather}

Rainfall and minimum daily temperature seemed to have little effect on the number of great crested newt movements. In autumn 2016, a greater number of great crested newts made movements in milder weather conditions $\left(R^{2}=9.0, F_{1,48}=\right.$ 4.66, $p=0.036$ ) but not in other seasons or years. Similarly, rainfall and temperature had little impact on the number of smooth newt movements, except in autumn 2015 when a greater number of smooth newts moved after rainfall $\left(R^{2}=15.8\right.$, $\left.F_{1,29}=5.27, p=0.029\right)$. Rainfall and minimum daily temperature had no significant impact on the movements of common frogs or common toads throughout all seasons and years.

\section{Peak movement times}

A significantly higher number of great crested newts moved at night, between 18:00 and 05:00, with peak movement times around midnight $\left(\chi_{23,375}^{2}=327.27, p<0.001\right)$ (Fig. 3). Virtually, no great crested newts were recorded in the tunnels during daylight hours, between 05:00 and 18:00. By contrast, smooth newt movements were distributed throughout a 24-h period with no significant association between the time of day and the number of smooth newts observed $\left(\chi_{23,129}^{2}=37.88\right.$, $p=0.05$ ) (Fig. 3). No analysis could be performed for common frogs since there were too many counts below the value of 5 . For common toads, however, a significantly greater number of individuals moved between 20:00 and 02:00 $\left(\chi_{23,184}^{2}=\right.$ $152.78, p<0.001)$.

\section{Pond surveys and occupancy analysis}

Repeated pond surveys and patch occupancy analysis estimates showed a rapid increase in peak counts and the population estimate of great crested newts occupying receptor ponds, from 59 individuals in 2014 (lower $\mathrm{CI}=54$; 
Table 2 Number of observations in tunnels of male and female great crested newts (GCN) and smooth newts, where sex identification was possible from dorsal view images

\begin{tabular}{cllllll}
\hline Time period & $\begin{array}{l}\text { Number of } \\
\text { male GCN }\end{array}$ & $\begin{array}{l}\text { Number of } \\
\text { female GCN }\end{array}$ & $\begin{array}{l}\text { GCN number } \\
\text { uncertain sex }\end{array}$ & $\begin{array}{l}\text { Number of male } \\
\text { smooth newt }\end{array}$ & $\begin{array}{l}\text { Number of female } \\
\text { smooth newt }\end{array}$ & $\begin{array}{l}\text { Smooth newt number } \\
\text { uncertain sex }\end{array}$ \\
\hline Autumn 2014 & 0 & 0 & 14 & 0 & 0 & 0 \\
Spring 2015 & 1 & 0 & 6 & 1 & 1 & 3 \\
Autumn 2015 & 7 & 24 & 10 & 1 & 9 & 8 \\
Spring 2016 & 6 & 12 & 0 & 5 & 11 & 0 \\
Autumn 2016 & 24 & 21 & 1 & 0 & 1 & 1 \\
Spring 2017 & 2 & 6 & 4 & 0 & 0 & 8 \\
Autumn 2017 & 19 & 18 & 68 & 0 & 0 & 18 \\
Total & 59 & 81 & 103 & 7 & 22 & 38 \\
\hline
\end{tabular}

upper $\mathrm{CI}=166$ ) to 300 individuals in 2017 (lower $\mathrm{CI}=$ 287; upper CI =862) (Table 3). Peak counts of six repeated annual counts using torch surveys also increased for great crested newts from 45 adults in 2014 to 70 adults in 2015, 130 adults in 2016 and 198 adults in 2017. Similar peak count increases were observed for smooth newts, from 43 adults in 2014 to 177 adults in 2017. Common toad peak counts increased from 0 to 1 in 2014-2015 to 155 individuals in 2017. Common frog numbers observed in the ponds remained very low, at 1-3 in 2014-2017. Importantly, the number of water bodies that hosted amphibians also increased rapidly, with amphibians moving across the road from the translocation ponds in the amphibian mitigation zone (Fig. 1) and colonising by 2017 nine of the ten water management ponds created in the immediate area.

\section{Discussion}

The monitoring of the tunnels and ponds indicates that this mitigation system provided a successful measure to prevent road mortality and a well-used movement corridor between aquatic habitats for great crested newts and other amphibian species. Equally, results show that adapted time-lapse camera technology provides a robust and relatively simple monitoring tool for such small road tunnels. All four amphibian species recorded in the original ponds were observed successfully

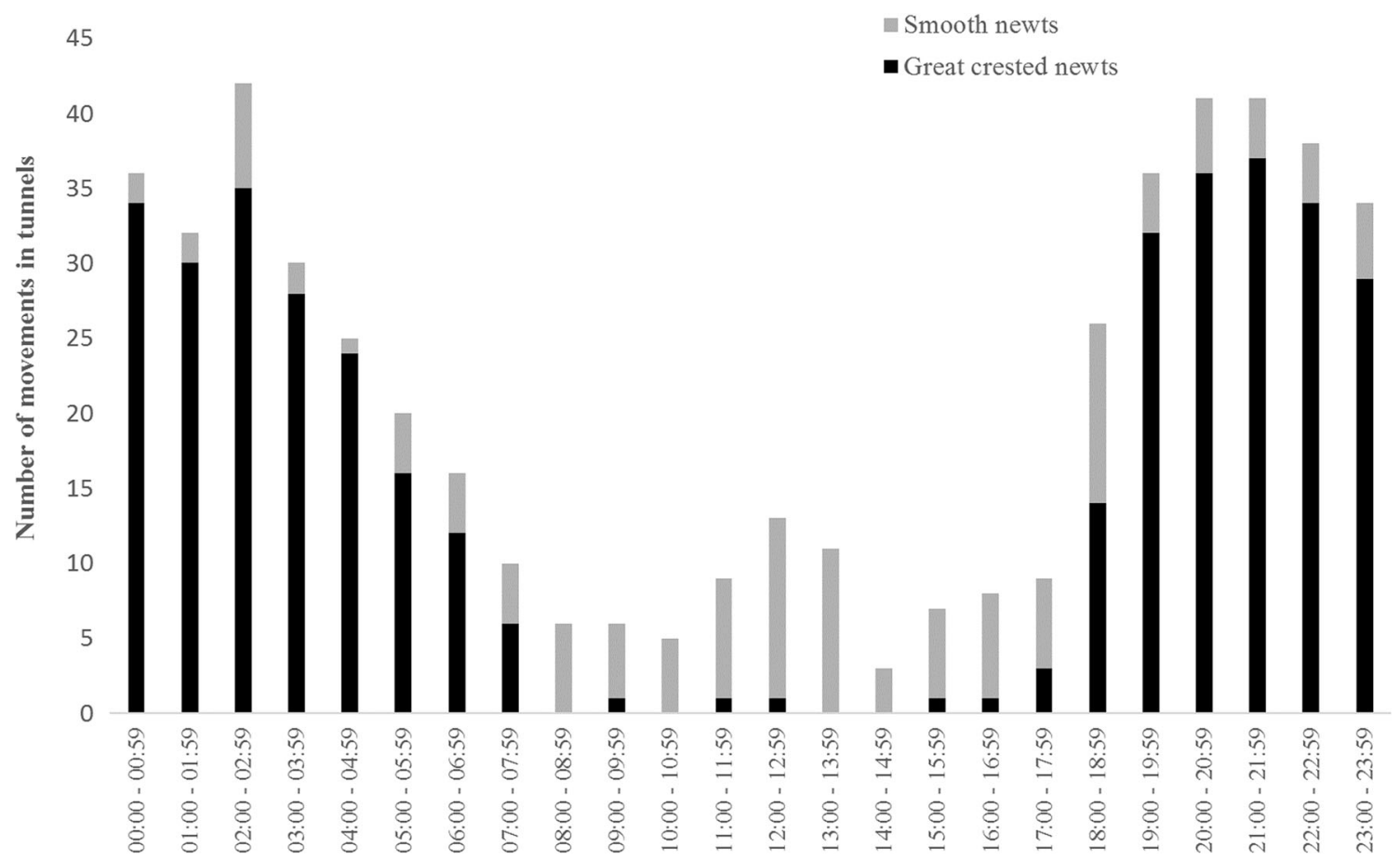

Fig. 3 Combined peak movement times in tunnels for great crested newts (Triturus cristatus) and smooth newts (Lissotriton vulgaris) across 24 h, all seasons and years 
Table 3 Estimates of population size of great crested newts $(\mathrm{GCN})$ in receptor ponds in 2014-2017

\begin{tabular}{lllll}
\hline Year & $\begin{array}{l}\text { Estimate (number individual } \\
\text { GCN in 16 ponds) }\end{array}$ & Standard error & $\begin{array}{l}\text { Lower 95\% } \\
\text { confidence interval }\end{array}$ & $\begin{array}{l}\text { Upper 95\% } \\
\text { confidence interval }\end{array}$ \\
\hline 2014 & 59.21 & 243 & 54.44 & 165.91 \\
2015 & 102.22 & 332 & 95.70 & 289.80 \\
2016 & 214.00 & 540 & 203.43 & 612.73 \\
2017 & 299.63 & 642 & 287.04 & 862.24 \\
\hline
\end{tabular}

using the tunnels in both spring and autumn seasons, and by 2017, most seemed to be increasing in numbers. No juvenile common frogs or common toads were recorded in the tunnels, most likely because their dispersal from the ponds following metamorphosis typically occurs in the summer months when no recording was being carried out. Studies aiming to assess accurately the mitigation effectiveness of tunnel and fence systems for these species should consider this and incorporate the summer period into monitoring.

\section{Tunnel success rate}

The tunnel success rate (i.e. the number of individuals making complete tunnel crossings) was highly variable between species and age classes, with a mean of $74.5 \%$ for great crested newts and $80.6 \%$ for smooth newts. Similar variation in tunnel success rates was observed in other studies of amphibians in road mitigation schemes. Bain et al. (2017) found that in the California tiger salamander (Ambystoma californiense), the average tunnel success rate was $51 \%$ and was affected by the amount of rainfall, but not the moisture levels, within the tunnels. However, the success rate can be as low as $12 \%$ for smooth newts in Germany (Brehm 1989) or 4\% for Ambystoma macrodactylum and Taricha granulosa (Malt 2012). In several anuran species moving through a tunnel system in North America, Pomezanski (2017) found that the success rate ranged between $53 \%$ and $91 \%$ and depended on tunnel substrate an environmental conditions. For great crested newts, Matos et al. (2018) found that most individuals reaching the mitigation fences did not encounter tunnel entrances, but once inside the tunnels, newt behaviour changed and movements became straighter; yet, even inside large 4.5-m-wide tunnels, only $18 \%$ made a full crossing. These studies, along with the results from our study, demonstrate that individual amphibian species have different preferences for tunnel conditions, which may vary depending on the time of day, weather and season. Our results show that, although tunnel success rate does vary, a significant number of individuals, both the protected great crested newts and the other three amphibian species present, did make full tunnel crossings. However, the crossing rate was highly variable, between and within species and age classes. For example, the crossing rate of juvenile great crested newts ranged from 0 to $81.2 \%$. Several potential factors could explain why there was such variation even within age classes of the same species. Amphibians have highly permeable skin and are prone to desiccation in dry tunnels (Rittenhouse et al. 2008). Although the tunnels in this study had air vents in the roof, which allowed free air exchange, the temperature, humidity and moisture levels in tunnels are likely to have been different to that in the wider environment at least temporarily. If conditions within tunnels were too dry, this may have deterred amphibians, especially smaller individuals since the risks of desiccation are high. Therefore, juvenile success rate may have been strongly dependent on the microclimate conditions of the tunnels on a given night. Tunnel substrate is also likely to impact on the likelihood that amphibians will travel through tunnels (Pomezanski 2017). Lesbarrères et al. (2004) found that agile frogs (Rana dalmatina) and water frogs (Rana esculenta) preferred tunnels lined with soil over those with a bare concrete surface, whereas toads did not discriminate between the tunnels' substrate. Similarly, juvenile western toads (Bufo boreas) and red-legged frogs (Rana aurora) showed greater movement rates in culverts with substrate as opposed to culverts without (Bernard 2000 [as cited in Fitzgibbon 2001]). In our study, adult common toads had a high tunnel success rate, which may be due to their lack of discrimination over the tunnel substrate along with their relatively large size and thicker, less permeable skin, which could decrease desiccation risk. Another factor affecting tunnel success rate might be the presence and quality of the surrounding drift fences. Several studies have shown that correctly constructed drift fences result in greater numbers of amphibians making tunnel crossings (Allaback and Laabs 2003; Pagnucco et al. 2011; Smith et al. 2010), whereas incomplete or broken fence sections result in road mortality and lower tunnel usage (Hill et al. 2018).

Despite repeated daytime and nocturnal site visits at regular and irregular intervals during the survey season, we did not record any live or dead amphibians on the fenced road section. Amphibian carcasses, particularly of juveniles, are very delicate and can disappear rapidly and thus it is impossible to be certain that there was no road mortality at all, but overall, we suggest that fences were adequate at preventing any significant amphibian road crossings and mortality.

\section{Numbers observed}

Similar to findings from another road mitigation site (Matos et al. 2017, 2018), results from our study show that both great 
crested and smooth newts moved in greater numbers through the tunnels in the autumn compared to the spring. Many pondbreeding amphibians in the UK make migratory movements towards ponds in the early spring and especially the males gain a reproductive advantage by wintering close to breeding ponds and by arriving early at breeding ponds (Latham and Oldham 1996; Reading 1998; Beebee 2007). The basis for most road mitigation measures comes from mass mortality records in the early spring, when amphibians migrate towards breeding ponds (Hels and Buchwald 2001; Schmidt and Zumbach 2008; Petrovan and Schmidt 2016). However, for newt species, it is likely that individual great crested and smooth newts are already close to breeding ponds by the time that tunnel monitoring started (mid-March) such that few individuals needed to make the required journey through tunnels to reach breeding ponds (Jehle and Artnzen 2000). The large number of great crested newts and smooth newts in the autumn is likely to be due to post-breeding and postmetamorphic dispersal (Jehle and Artnzen 2000; Berger et al. 2011). At this time of year, individuals may have been seeking wider habitats for foraging and/or ponds for the following breeding season. We observed a higher number of juveniles of both species during the autumn, which indicates post-metamorphic dispersal into new habitats was important at this time of year.

The numbers of common toads observed in tunnels indicate that a high number of individuals moved in spring but not in autumn. This result is not surprising since common toads exhibit an explosive breeding strategy, arriving at ponds and leaving within a few days (Reading 1998; Beebee and Griffiths 2000). We commonly observed common toads entering tunnels and then returning through them a few days later. Common toads generally migrate to ponds from further distances than other UK amphibian species, which may also explain their higher occurrence in tunnels in spring (Daversa et al. 2012). Alternatively, the over-wintering sites for common toads may have been further from breeding ponds compared to the newt species as has been recorded in other studies on this species (Sinsch 1988).

\section{Sex ratio}

Although the results from sex ratio remain inconclusive, preliminary data shows that female great crested and smooth newts may make longer distance post-breeding migrations than males, which is similar to the findings at another UK site (Matos et al. 2017). Sinsch (1992) found similar results in the natterjack toad (Epidalea calamita) where $90 \%$ of males exhibited breeding site fidelity, whereas females moved between ponds to maintain gene flow. In a population study on great crested newts in the UK, Williams (1999) recorded only four movements between ponds over the 3-year study period, all of which were female. These results suggest that it is the movement of females between breeding ponds, rather than males, that promotes population dispersal and gene flow. This should be further investigated in order to improve understanding of metapopulation connectivity including for road mitigation schemes.

\section{Influence of weather}

Unexpectedly, in this study, rainfall and minimum daily temperature had little impact on the number of amphibians observed moving in tunnels. Other studies have shown a link between weather conditions, particularly levels of rainfall, and the number of amphibian movements in tunnels (Bain et al. 2010; Pomezanski 2017) or general newt activity levels along mitigation fences and tunnels (Matos et al. 2018). In addition, numerous studies have shown a link between the timing of amphibian breeding with weather conditions (Verrell and Halliday 1985; Andreone and Giacoma 1989; Reading 1998). However, these studies indicate that it is the rainfall and temperature in the few days preceding migration which triggers movements. Results from our study suggest that by the time amphibians have started migration, temperature and rainfall may have less of an effect as long as extremes are avoided. Tunnel conditions may be influenced especially by rainfall events, increasing the moisture and humidity levels within the tunnels. We did not observe any differences in the number of amphibians using tunnels after rainfall, which indicates that there may be several factors, other than tunnel moisture levels, that promote effective use of amphibians in tunnels. In our site, the water table was generally high, a factor that also influenced the type of tunnels used as wider $(1 \mathrm{~m})$ concrete box culverts that sit entirely below the road surface were considered at high risk of long-term flooding. In the long-toed salamander, Pagnucco et al. (2012) also found that in the spring, movement through tunnels was not strongly dependent on precipitation and Reading (1998) noted no effect of rainfall in the timing of migration in the common toad. Therefore, the influence of climatic conditions on the number of movements through tunnels may vary depending on species, site and tunnel-specific factors such as tunnel length, diameter, substrate type as well as site positioning, vegetation type and water table. For small and long tunnels, open vents at the top are most likely particularly important in minimising temperature and humidity variations between the tunnel microclimate and the external environment. However, such open vents also allow road pollutants, including salt for road deicing as well as heavy metals, to wash into the tunnels, with substantial contamination consequences in both tunnels and nearby areas (White et al. 2017). Whilst we did not observe any direct consequences of this chemical contamination, this aspect should be carefully monitored and mitigated, for instance by washing the tunnels with clean water in early spring and directing the resulting water away from the ponds. 


\section{Peak movement times}

Great crested newts exhibited high levels of activity during night time hours, with virtually no movements in the tunnels during the day, despite the proximity between the tunnels and the ponds. These results confirm findings from other studies that show that this species is strictly nocturnal (Dolmen 1983; Gustafson et al. 2007). However, smooth newts exhibited both diurnal and nocturnal activity, which is in contrast to Dolmen (1983) who states that smooth newts are primarily nocturnal or crepuscular. Our results suggest that smooth newts are as likely to be as observed in tunnels during the day as at night. Common toad adults also exhibited strictly nocturnal activity, with peak activity between 22:00 and 02:00. These results are important as they indicate how to target monitoring periods in order to record road mitigation usage for a variety of species. Understanding peak activity patterns also provides important data for quantifying road mortality risks for different species and life stages given that most roads experience a drastic reduction of traffic values at night.

\section{Pond occupancy}

Pond occupancy by great crested newts increased rapidly over the 4-year study period, both in terms of estimated numbers as well as numbers of ponds occupied. Previous studies on pond occupancy have shown increases in population size following installation of tunnels as a mitigation for road construction (Jolivet et al. 2008; Smith et al. 2010).

\section{Conclusions}

Results from this study indicate that at this mitigation system, small, open vent road tunnels provided an effective corridor for movements and site connectivity for four amphibian species native to the UK, including the protected great crested newt. The local population appears to have increased rapidly over the 4-year study period, suggesting that effective habitat replacement and management, together with the tunnels to link habitat, have successfully promoted population persistence and expansion through colonisation of the water bodies across the road. The main implication of the road tunnel and fence system affecting mainly newt dispersal in autumn rather than spring breeding migrations is that it makes it imperative for such road mitigation projects to connect suitable breeding habitats on both sides of the road as opposed to terrestrial habitat on one side and aquatic habitat on the other side. We demonstrate that when tunnel mitigation systems are installed close to ponds, with effective drift fences along with provision of additional ponds and suitable terrestrial habitat, that amphibian population persistence can be maintained and enhanced by movements through tunnels but those movements are species specific. Future projects should aim to maximise the impact of road mitigation schemes via strategic implementation designed to minimise road mortality and promote landscape-scale metapopulation connectivity.

Acknowledgements We are grateful to Natural England, URS Ecology and AECOM for their assistance and collaborative support and in particular Jo Atkinson and Paul Edgar. We thank Frank Clark and Gilles Dubois for assistance with equipment creation and installation.

Funding information At Froglife, Laurence Jarvis and Silviu Petrovan were supported by the Esmée Fairbairn Foundation and the John Ellerman Foundation. Michael Hartup and Silviu Petrovan were supported in this project by grants from the People's Trust for Endangered Species.

Open Access This article is distributed under the terms of the Creative Commons Attribution 4.0 International License (http:// creativecommons.org/licenses/by/4.0/), which permits unrestricted use, distribution, and reproduction in any medium, provided you give appropriate credit to the original author(s) and the source, provide a link to the Creative Commons license, and indicate if changes were made.

Publisher's note Springer Nature remains neutral with regard to jurisdictional claims in published maps and institutional affiliations.

\section{References}

Allaback ML, Laabs DM (2003) Effectiveness of road tunnels for the Santa Cruz Long-toed Salamander. Trans Western Section Wildl Soc 38:5-8

Andreone F, Giacoma C (1989) Breeding dynamics of Triturus carnifex at a pond in northwestern Italy (Amphibia, Urodela, Salamandridae). Holarct Ecol 12:219-223

Bain TK, Cook DG, Girman DJ (2017) Evaluating the effects of abiotic and biotic factors on movement through wildlife crossing tunnels. Herpetol Conserv Biol 12:192-201

Beebee TJC (2007) Thirty years of garden ponds. Brit Herp Bull 99:23-28

Beebee TJC (2013) Effects of road mortality and mitigation measures on amphibian populations. Conserv Biol 27:657-668

Beebee TJC, Griffiths RA (2000) Amphibians and reptiles. HarperCollins, vol 270. New Naturalist, London

Bernard D (2000) Unpublished environmental monitor's report submitted to the Vancouver Island highway project. Ministry of Transportation and Highways. Victoria, British Columbia, Canada.

Berger G, Pfeffer H, Kalettka T (2011) Amphibienschutz in kleingewässerreichen Ackerbaugebieten Natura \& Text, Rangsborg, 384 pp.

Brehm K (1989) The acceptance of 0.2-m tunnels by amphibians during their migration to the breeding site. In: Langton T (ed) Amphibians and roads: proceeding of the toad tunnel conference. ACO Polymer Products, England, p 202

Daversa DR, Muths E, Bosch J (2012) Terrestrial movement patterns of the common toad (Bufo bufo) in central Spain reveal habitat of conservation importance. J Herpetol 46:658-664

Dolmen D (1983) Diel rhythms and microhabitat preferences of the newts Triturus vulagris and T cristatus at the northern border of their distribution area. J Herpetol 17:23-31

English Nature (2001) Great crested newt mitigation guidelines. English Nature, Peterborough, UK 
Fahrig L, Pedlar JH, Pope SE, Taylor PD, Wegner JF (1995) Effect of road traffic on amphibian density. Biol Conserv 73:177-182

Fitzgibbon K (2001) An evaluation of corrugated steel culverts as transit corridors for amphibians and small mammals at two Vancouver Island wetlands and comparative culvert trials. MSc thesis, Royal Roads University, Vancouver, British Columbia, Canada

Furnborough PA (2016) Ecology and conservation of a superabundant great crested newt Triturus cristatus population in a multi-pond postindustrial landscape using occupancy modelling. MSc thesis, University of Hull, UK

Glista DJ, DeVault TL, DeWoody JA (2008) Vertebrate road mortality predominantly impacts amphibians. Herpetol Conserv Biol 3:77-87

Griffiths RA, Sewell D, McCrea R (2010) Dynamics of a declining amphibian metapopulation: survival, dispersal and the impact of climate. Biol Conserv 143:485-491

Gustafson DH, Pettersson CJ, Malmgren JC (2007) Great crested newts (Triturus cristatus) as indicators of aquatic plant diversity. Herpetol J $16: 347-352$

Halley JM, Oldham RS, Arntzen JW (1996) Predicting the persistence of amphibian populations with the help of a spatial model. J Anim Ecol $33: 455-470$

Helldin JO, Koffman A, Söderström-Lööf C, Jondelius E, Hartup M, Petrovan SO (2015) Groddjurstunnlar Spångavägen Rapport 201510-02, Calluna Consultancy (in Swedish, available at http:// miljobarometernstockholmse/content/docs/tema/natur/Groddjur/ Groddjurstunnlar\%20Sp\% C3\% A 5ngav\% C3\% A4gen\% 20Rapport\%202015-10-02pdf)

Hels T, Buchwald E (2001) The effect of road kills on amphibian populations. Biol Conserv 99:331-340

Hill IDC, Rossi CA, Petrovan SO, Hartup M, Clark F \& Downie JR (2018) Mitigating the effects of a road on amphibian migrations: a Scottish case study of road tunnels. The Glasgow Naturalist, Volume 27, Supplement The Amphibians and Reptiles of Scotland

Jehle R, Artnzen JW (2000) Post-breeding migrations of newts (Triturus cristatus) and (T. marmoratus) with contrasting ecological requirements. J Zool (Lond) 251:297-306

Jolivet R, Antionazza M, Strehler-Perrin C, Gander A (2008) Impact of road mitigation measures on amphibian populations: a stage-class population mathematical model. Cornell University Library, Ithaca, New York Available from http://arxivorg/abs/08064449 (accessed February 2016)

Kyek M, Kaufmann PH, Lindner R (2017) Differing long term trends for two common amphibian species (Bufo bufo and Rana temporaria) in alpine landscapes of Salzburg. Austria PLOS ONE 12:e187148

Langton TES, Beckett CL, Foster JP (2001) Great crested newt conservation handbook. Froglife, Halesworth

Latham DM, Oldham RS (1996) Woodland management and conservation of the great crested newt (Triturus cristatus). Aspect App Biol 44:451-459

Lesbarreres D, Fahrig L (2012) Measures to reduce population fragmentation by roads: what has worked and how do we know? TREE 27 : 374-380

Lesbarrères D, Lodé T, Merilä J (2004) What type of amphibian tunnel could reduce road kills? Oryx 38:220-223

MacKenzie, D.I., Nichols, J.D., Royle, J.A., Pollock, K.H., Bailey, L. and Hines, J.E., (2006) Occupancy estimation and modeling: inferring patterns and dynamics of species occurrence. Elsevier

Malt J (2012) Assessing the effectiveness of amphibian mitigation on the sea to sky highway: population-level effects and best management practices for minimizing highway impacts. Ministry of forests, lands, and natural resource operations. Final report. pp. 1-33

Matos C, Petrovan S, Ward AI, Wheeler P (2017) Facilitating permeability of landscapes impacted by roads for protected amphibians: patterns of movement for the great crested newt. Peer J 5:e2922. https:// doi.org/10.7717/peerj2922
Matos C, Petrovan S, Ward AI, Wheeler P (2018) Short-term movements and behaviour govern the use of road mitigation measures by a protected amphibian. Anim Conserv. https://doi.org/10.1111/acv.12467

Mazerolle MJ (2004) Amphibian road mortality in response to nightly variations in traffic intensity. Herpetologica 60:45-53

Pagnucco KS, Paszkowski CA, Scrimgeour GJ (2011) Using cameras to monitor tunnel use by long-toed salamanders (Ambystoma macrodactylum): an informative, cost-efficient techniques. Herpetol Conserv Biol 6:277-286

Pagnucco KS, Paszkowski CA, Scrimgeour GJ (2012) Characterizing movement patterns and spatio-temporal use of under-road tunnels by Long-toed Salamanders in Waterton Lakes National Park, Canada. Copeia 2012:331-340

Patrick DA, Schalk CM, Gibbs JP, Woltz HW (2010) Effective culvert placement and design to facilitate passage of amphibians across roads. J of Herp 44:618-626

Petrovan SP, Schmidt BR (2016) Volunteer conservation action data reveals large-scale and long-term negative population trends of a widespread amphibian, the common toad (Bufo bufo). PLoS One 11(10):e0161943. https://doi.org/10.1371/journalpone0161943

Pomezanski D (2017) Monitoring small animal usage patterns of suburban wildlife tunnels: behaviour, design, and recommendations MSc thesis, University of Guelph, Guelph, Ontario, Canada

Reading CJ (1998) The effect of winter temperatures on the timing of breeding activity in the common toad Bufo bufo. Oecologia 117: 469-475

Rittenhouse TAG, Harper EB, Rehard LR, Semlitsch RD (2008) The role of microhabitats in the desiccation and survival of amphibians in recently harvested oak-hickory forest. Copeia 2008(807):814

Schmidt BR, Zumbach S (2008) Amphibian road mortality and how to prevent it: a review. In: JC Mitchell, RE Jung Brown, R Bartolomew. Urban Herpetology. St. Louis, Missouri, 157-167

Sinsch U (1988) Seasonal changes in the migratory behaviour of the toad Bufo bufo: direction and magnitude of movement. Oecolgia 76:390 398

Sinsch U (1992) Structure and dynamic of a natterjack toad metapopulation (Bufo calamita). Oecologia 90:489-499

Smith C, Pagnucco K, Johnston B, Paszkowski C, Scrimgeour G (2010) Using specialized tunnels to reduce highway mortality of amphibians. Pp 583-591 In Proceedings of the 2009 International Conference on Ecology and Transportation Wager. In PJD Nelson, E Murray (Eds) Center for Transportation and the Environment, North Carolina State University, Raleigh, North Carolina, USA

Smith RK, Meredith H, Sutherland WJ (2018) Amphibian conservation. In: Sutherland WJ, Dicks LV, Ockendon N, Petrovan SO, Smith RK (eds) What works in conservation 2018. Open Book Publishers, Cambridge, UK, pp 9-65

Van der Grift EA, Van der Ree R, Fahrig L, Findlay S, Houlahan J, Jaeger JAG, Klar N, Madrinan LF, Olson L (2013) Evaluating the effectiveness of road mitigation measures. Biodivers Conserv 22:425-448

Van der Ree R, Jaeger JAG, Rytwinski T, van der Grift E (2015) Good science and experimentation are needed in road ecology. In: van der Ree R, Smith D, Grilo C (eds) Handbook of road ecology. John Wiley \& Sons, Oxford, pp 71-81

Verrell P, Halliday T (1985) Reproductive dynamics of a population of smooth newts, Triturus vulgaris, in southern England. Herpetologica 41:386-395

White KJ, Mayes WM, Petrova SO (2017) Identifying pathways of exposure to highway pollutants in great crested newt (Triturus cristatus) road mitigation tunnels. Water Environ J 31:310-316

Williams C (1999) Metapopulation dynamics of the crested newt, Triturus cristatus. PhD Thesis, Durrell Institute of Conservation and Ecology, University of Kent, UK 